\title{
Liver phosphorus content in Holstein-Friesian cows during the transition period
}

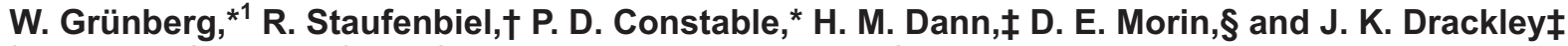 \\ ${ }^{*}$ Department of Veterinary Clinical Sciences, Purdue University, West Lafayette, IN 47907 \\ †Klinik für Klauentiere, Freie Universität Berlin, 14163 Berlin, Germany \\ $\S$ Department of Veterinary Clinical Medicine, and \\ $\ddagger$ Department of Animal Sciences, University of Illinois at Urbana-Champaign, Urbana 61801
}

\begin{abstract}
Hepatic lipidosis and hypophosphatemia are frequently observed in high-yielding periparturient dairy cows. Objectives of this study were to investigate the association of the liver $\mathrm{P}$ content with the degree of liver fat accumulation and serum $\mathrm{P}$ concentration and to characterize the change in liver $\mathrm{P}$ content throughout the transition period. In a cross-sectional study, liver biopsies obtained from 33 Holstein-Friesian cows $14 \mathrm{~d}$ postpartum (p.p.) were assayed for total lipid (TLip), triacylglycerol, DNA, P, Mg, K, Na, and Ca content. Serum samples obtained at the time of biopsy were analyzed for indices of liver function and injury and the serum P concentration was determined. From this cross-sectional study, 6 cows were selected for a longitudinal study and liver tissue obtained from the 6 cows on $\mathrm{d}-65,-30,-14,1,14,28$, and 49 relative to calving was assayed. The amounts of $\mathrm{P}, \mathrm{K}, \mathrm{Mg}, \mathrm{Na}$, and Ca were expressed as amount in dry weight (DW), wet weight $(\mathrm{WW})$, nonfat wet weight $(\mathrm{NFWW})$, and indexed to DNA. In the cross-sectional study, $\mathrm{P}_{\mathrm{DW}}$ and $\mathrm{P}_{\mathrm{WW}}$ decreased with increasing TLip, whereas $\mathrm{P}_{\mathrm{NFWW}}$ and $\mathrm{P}_{\mathrm{DNA}}$ were independent of TLip. Values for $\mathrm{P}_{\mathrm{DNA}}$ varied widely, whereas $\mathrm{P}_{\mathrm{NFWW}}$ varied within a narrow range. Stepwise regression analysis revealed the strongest associations between $\mathrm{P}_{\mathrm{DW}}$ and the amount of tissue water (partial $R^{2}=0.74$ ) and the $\log$ to the base 10 of triacylglycerol (partial $\mathrm{R}^{2}=0.05$ ). The $\mathrm{P}_{\mathrm{Ww}}$ was associated with the $\log$ to the base 10 of triacylglycerol (partial $\mathrm{R}^{2}=0.20$ ), but no associations were found for

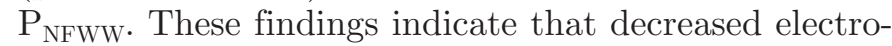
lyte content in dry and wet liver tissue with increased liver lipid content is predominantly due to the decrease in tissue water and therefore the distribution volume of electrolytes. In the longitudinal study, $\mathrm{P}_{\mathrm{DW}}, \mathrm{P}_{\mathrm{WW}}$, and $\mathrm{P}_{\text {NFWW }}$ were decreased on d 14 p.p. Similar directional decreases were found for $\mathrm{K}, \mathrm{Mg}$, and $\mathrm{Na}$, but $\mathrm{P}$ was
\end{abstract}

Received November 12, 2008.

Accepted January 7, 2009.

${ }^{1}$ Corresponding author: waltergruenberg@yahoo.com the only electrolyte that was significantly decreased in liver tissue at d 14 p.p. This finding indicates that the $\mathrm{P}$ content of liver tissue decreases in early lactation due to a reduction in hepatocellular cytosol volume as well as a decrease in cytosolic P concentration, with the latter having biological relevance. The clinical significance of decreased cytosolic $\mathrm{P}$ concentration in the hepatocytes of dairy cows in early lactation remains to be determined.

Key words: hepatic lipidosis, hypophosphatemia, hepatocyte, fatty liver

\section{INTRODUCTION}

Hepatic lipidosis (fatty liver syndrome) is a common disorder of high-yielding dairy cows during early lactation (Bobe et al., 2004). The disorder is associated with decreased productivity and reproductive performance, increased morbidity, and death in severely affected animals. Hepatic lipidosis is caused by a transient but acute state of negative energy balance in early lactation, which results in mobilization of large amounts of body fat, a concomitant increase in plasma NEFA concentration, and accumulation of lipids in the liver (Drackley, 1999). Clinical signs associated with hepatic lipidosis include decreased DMI and depression (Reid, 1980).

Hypophosphatemia, defined as serum or plasma phosphate concentration below $4 \mathrm{mg} / \mathrm{dL}$, is a common clinicopathologic finding in sick cows in the periparturient period that has been attributed to decreased DMI (Grünberg et al., 2005). Retrospective studies have identified weak but significant negative correlations between serum or plasma inorganic $\mathrm{P}$ concentration $([\mathbf{P i}])$ and indices of hepatic injury [e.g., aspartate aminotransferase (AST) activity] or decreased liver function (e.g., total bilirubin concentration) in dairy cows (Staufenbiel and Gelfert, 2002; Grünberg et al., 2005). Although an association between serum $[\mathrm{Pi}]$ and indices of hepatic injury or decreased function is well recognized in human medicine (Baquerizo et al., 2003), the underlying mechanism is not well understood. Impaired 
cellular metabolic activity is likely to be present in states of intracellular P depletion because the availability of intracellular Pi directly affects intracellular biochemical reactions that depend on phosphorylation (Balaban, 1984). In contrast to humans where disturbed liver function and liver failure is usually the result of acute or chronic intoxication (Knochel, 1977), liver failure in the transition cow is most commonly due to excessive liver lipid accumulation (Knochel, 1977; Dawson et al., 1987; Bobe et al., 2004). To our knowledge, the effect of hepatic lipidosis on $\mathrm{P}$ homeostasis and liver $\mathrm{P}$ content has not been studied in the dairy cow.

We hypothesized that liver lipid accumulation in dairy cows during early lactation was associated with decreased $\mathrm{P}$ content in liver tissue. The goals of the study reported here were to characterize the relationship between hepatocellular lipid and P content in early lactation dairy cows, to characterize the change in liver $\mathrm{P}$ content throughout the transition period, and to determine whether serum $[\mathrm{P}]$ is associated with liver $\mathrm{P}$ content in dairy cows.

\section{MATERIALS AND METHODS}

\section{Animals and Housing}

Eighty healthy late-gestation multiparous HolsteinFriesian cows on the University of Illinois Dairy Farm were fed a TMR. The cows ranged in age from 3 to $7 \mathrm{yr}$ and were randomly assigned to be fed different combinations of far-off and close-up diets that provided 80 to $150 \%$ of net energy requirements recommended by the NRC (2001). All other nutrients, including P, were fed to meet or slightly exceed recommendations (NRC, 2001). The far-off, close-up, and lactating cow rations contained $0.30,0.37$, and $0.47 \% \mathrm{P}$ of the dietary DM. All animal procedures had been approved by the Institutional Animal Care and Use Committee of the University of Illinois at Urbana-Champaign.

\section{Cross-Sectional Study}

Blood and liver and serum samples were obtained from the 80 cows on d 14 postpartum (p.p.) during previous studies (Dann et al., 2006; our unpublished data). Blood samples were collected from the coccygeal vein or artery into evacuated serum separator tubes before the morning feeding and immediately before biopsy. Serum was obtained by centrifugation at 1,300 $\times g$ for $15 \mathrm{~min}$ and stored at $-20^{\circ} \mathrm{C}$ until analyzed. Liver biopsy samples were obtained via puncture biopsy as described (Hughes, 1962; Veenhuizen et al., 1991) under local anesthesia at approximately $0700 \mathrm{~h}$, which was after the morning milking but before the first feeding of the day. Hepatic tissue was immediately placed in liquid nitrogen and stored at $-80^{\circ} \mathrm{C}$ until analyzed for total lipids (TLip; Hara and Radin, 1978) and triacylglycerol (TAG; Fletcher, 1968; Foster and Dunn, 1973).

A sampling strategy was employed to produce a broad range of evenly distributed hepatic TAG values. The sampling strategy was required to optimize the statistical analysis because hepatic TAG values for the 80 cows had a marked left-skew distribution. We therefore ranked the 80 liver biopsy samples by TAG content and grouped cows into TAG quartiles. Liver biopsy and serum samples from every fifth cow in the first TAG quartile were included, as well as liver biopsy and serum sample from every third cow in the second, third, and fourth TAG quartiles. This stratification procedure provided a total of 33 biopsy specimens and serum samples. Stored liver biopsy and serum samples from the 33 cows on d 14 p.p. were retrieved from storage to investigate the association between the liver $\mathrm{P}$ content and the degree of liver fat accumulation, indices of liver function, and serum $\mathrm{P}$ concentration.

\section{Longitudinal Study}

A power analysis using $\alpha=0.05$ and power $=0.80$ was performed to calculate the number of animals needed to detect a decline in cytosolic $\mathrm{P}$ concentration from calving to d 14 p.p. from $4.0 \mathrm{mg} / \mathrm{g}$ of nonfat liver tissue to $3.2 \mathrm{mg} / \mathrm{g}$, equivalent to a $20 \%$ decline using the standard deviation of $0.2 \mathrm{mg} / \mathrm{g}$ determined in the cross-sectional study. The power calculation indicated that a sample size of 6 animals was sufficient. Accordingly, liver TAG contents on d 14 p.p. for the 33 cows in the cross-sectional study were ranked and divided into tertiles representing low ( 0.2 to $2.4 \%$ ), moderate (2.5 to $6.2 \%$ ), and high (6.3 to $19.9 \%$ ) liver TAG content. Two animals were selected randomly from each tertile; this provided 2 cows with low, 2 with moderate, and 2 with high liver TAG content on d 14 p.p. Stored liver biopsy samples that had been collected from the 6 cows on $\mathrm{d}$ $-65,-30,-14,+1,+28$, and +49 relative to calving were retrieved and analyzed. Serum samples that had been collected from the 6 cows on $\mathrm{d}-50,-36,-14,1$, 28 , and 49 relative to calving were also retrieved and analyzed to characterize the change in liver $\mathrm{P}$ content and serum biochemical parameters throughout the transition period.

\section{Laboratory Analysis of Liver Samples}

The total amount of $\mathrm{P}, \mathrm{K}, \mathrm{Na}, \mathrm{Mg}$, and $\mathrm{Ca}$ in liver tissue was determined via inductively coupled plasma mass spectrometry after drying tissue samples at $95^{\circ} \mathrm{C}$ 
to constant weight (Braselton et al., 1997). The DNA content was determined quantitatively according to a modification of the method used by Labarca and Paigen (1980), as described previously (Kim et al., 1999), and was expressed as milligrams per gram of wet liver tissue. Electrolyte contents measured in dry liver tissue were expressed as micrograms per gram or milligrams per gram of dry weight.

The electrolyte contents in dry liver tissue were converted to contents in wet liver weight based on the previously determined amount of tissue water $(\mathbf{W})$ and to contents in nonfat wet liver weight. This latter conversion was obtained by subtracting the TLip from liver wet weight and expressing the content of each electrolyte as a fraction of this nonfat wet liver weight. Removal of the fat fraction that is not contributing to the volume of distribution of ionized intracellular electrolytes was anticipated to produce a better estimate of the electrolyte concentrations in $\mathrm{W}$ and thus in intracellular water.

To explore a potential confounding effect of change in hepatocellular volume on the measured values, the concentrations of electrolytes in dry liver specimens were indexed to DNA content and expressed as micrograms per microgram of DNA. The percentage of $\mathrm{W}$ in the total wet liver sample was calculated for each sample using the formula $\mathrm{W}=[$ (wet weight - dry weight $) /$ wet weight $] \times 100$. Total $\mathrm{W}$ in this study was used as a proxy for intracellular water and thus the distribution volume for predominantly intracellular electrolytes. Changes in total hepatocellular volume were crudely estimated by determining changes in the sum of the percentages of intracellular water and TLip $(\mathbf{W}+$ TLip). This approach was based on the assumption that the fraction of fat-free DM and extracellular fluid in the liver remain constant and that changes in cell volume are equivalent to the sum of the changes occurring in the fat and intracellular water fraction.

\section{Serum Biochemical Analysis}

Samples collected on d 14 p.p. were thawed at room temperature and assayed for serum concentrations of total protein, albumin, glucose, [BHBA], urea, cholesterol ([CHOL]), $[\mathrm{Na}],[\mathrm{K}],[\mathrm{Ca}], \mathrm{P},[\mathrm{Mg}]$, and total bilirubin, as well as activities of alkaline phosphatase, AST, $\gamma$-glutamyl transferase, and sorbitol dehydrogenase, using an automated analyzer (Hitachi 911, Roche Diagnostic, Basel, Swizerland). Concentrations of NEFA ([NEFA]) in the serum samples were determined enzymatically using a commercial test kit (NEFA test kit; Wako Chemicals USA Inc., Richmond, VA), as modified by Johnson and Peters (1993). Serum immunoreactive insulin concentrations were measured using a RIA kit validated for cattle (Coat-a-Count insulin kit; Diagnostic Products Corporation, Los Angeles, CA; Trenkle, 1972), as modified by Studer et al. (1993).

Serum samples obtained at $-50,-36,-14,1,28$, and $49 \mathrm{~d}$ relative to calving from cows included in the longitudinal study were analyzed for serum $[\mathrm{Ca}],[\mathrm{P}]$, $[\mathrm{Mg}],[\mathrm{Na}],[\mathrm{K}]$, urea, total protein, glucose, [BHBA], [NEFA], and immunoreactive insulin concentrations.

\section{Milk Yield and Feed Intake}

Milk yield and DMI data were available for 27 of the 33 cows in the cross-sectional study. Mean milk yield and DMI for the $5 \mathrm{~d}$ before performing the liver biopsy (d 9 to 13 p.p.) were calculated for each cow.

\section{Statistical Analysis}

Results are expressed as mean \pm standard deviation or as geometric mean (GEM) and interquartile range for parameters not normally distributed. Values were log-transformed when necessary to obtain a normal distribution before statistical analysis was performed. A statistical software package (9.1, SAS Institute Inc., Cary, NC) was used for statistical analysis and a $P$ value $<0.05$ was considered significant.

For the cross-sectional study, linear associations between study variables on d 14 p.p. were investigated by calculating Pearson correlation coefficients; this included associations between liver $\mathrm{P}$ content in dry weight $\left(\mathbf{P}_{\mathrm{DW}}\right)$, wet weight $\left(\mathbf{P}_{\mathrm{Ww}}\right)$, and nonfat wet weight $\left(\mathbf{P}_{\text {NFww }}\right)$; liver P content indexed to DNA content $\left(\mathbf{P}_{\text {DNA }}\right)$; liver $\mathrm{K}, \mathrm{Ca}, \mathrm{Mg}$, and $\mathrm{Na}$ contents; liver TLip and TAC concentrations; serum biochemical values; milk yield; and DMI. The mean CV was calculated for liver $\mathrm{P}, \mathrm{K}, \mathrm{Mg}, \mathrm{Na}$, and $\mathrm{Ca}$ contents expressed on a dry weight, wet weight, nonfat wet weight, or DNA content basis. Backward and forward multiple stepwise regression analyses were also performed $(P<0.05$ for entry and exit), with TAG, TLip, milk yield, DMI, and serum biochemical parameters as independent variables and $\mathrm{P}_{\mathrm{DW}}, \mathrm{P}_{\mathrm{WW}}, \mathrm{P}_{\mathrm{NFWW}}$, or $\mathrm{P}_{\mathrm{DNA}}$ as dependent variables. Linear associations between liver TAG and $\mathrm{W}$ or $\mathrm{W}$ + TLip were investigated using Pearson correlation coefficients. To investigate a possible carryover effect of dietary treatment before calving on measured liver parameters, samples of 33 cows were grouped into 5 groups according to the dietary treatment combination they received during far-off and close-up dry periods and an ANOVA was performed to determine group differences. An analysis of covariance with the amount of DNA in liver tissue as a covariate was performed to adjust for the effect of DNA. 
LIVER PHOSPHORUS IN DAIRY COWS

Table 1. Electrolyte content (mean $\pm \mathrm{SD}$ ) in liver tissue of 33 Holstein-Friesian cows on d 14 postpartum

\begin{tabular}{lcccc}
\hline Electrolyte & Dry weight & Wet weight & Nonfat wet weight & Indexed to DNA $(\mu \mathrm{g} / \mu \mathrm{g} \text { of DNA })^{1}$ \\
\hline $\mathrm{P}(\mathrm{mg} / \mathrm{g})$ & $8.99 \pm 1.51$ & $2.91 \pm 0.27$ & $3.25 \pm 0.23$ & $2.76 \pm 1.00$ \\
$\mathrm{CV}(\%)$ & 16.9 & 9.4 & 7.1 & 36.3 \\
$\mathrm{~K}(\mathrm{mg} / \mathrm{g})$ & $7.90 \pm 1.49$ & $2.56 \pm 0.30$ & $2.86 \pm 0.29$ & $2.44 \pm 1.01$ \\
$\mathrm{CV}(\%)$ & 18.9 & 11.8 & 10.0 & 41.2 \\
$\mathrm{Mg}(\mu \mathrm{g} / \mathrm{g})$ & $461.1 \pm 84.5$ & $149.0 \pm 14.7$ & $166.5 \pm 11.5$ & $0.14 \pm 0.05$ \\
$\mathrm{CV}(\%)$ & 18.3 & 9.8 & 6.9 & 37.9 \\
$\mathrm{Na}(\mathrm{mg} / \mathrm{g})$ & $3.45 \pm 0.97$ & $2.72 \pm 0.14$ & $3.0 \pm 1.5$ & $2.26 \pm 1.30$ \\
$\mathrm{CV}(\%)$ & 27.9 & 52.0 & 49.9 & 57.5 \\
$\mathrm{Ca}(\mu \mathrm{g} / \mathrm{g})$ & $162.6 \pm 44.9$ & $52.4 \pm 10.5$ & $58.8 \pm 12.1$ & $0.05 \pm 0.02$ \\
$\mathrm{CV}(\%)$ & 27.6 & 20.1 & 20.6 & 37.1 \\
\hline
\end{tabular}

${ }^{1}$ Values from 26 cows.

For the longitudinal study, repeated measures ANOVA was performed using a first-order autoregressive model to identify differences in measured parameters over time to characterize the change in liver $\mathrm{P}$ content throughout the transition period. Bonferroni-adjusted $P$-values were used when indicated by significant $\mathrm{F}$ test. To determine whether serum $[\mathrm{P}]$ was associated with liver $\mathrm{P}$ content, regression analyses were performed for every time point with serum $[\mathrm{P}]$ as the independent variable and $\mathrm{P}_{\mathrm{DW}}, \mathrm{P}_{\mathrm{WW}}, \mathrm{P}_{\mathrm{NFWw}}$, and $\mathrm{P}_{\mathrm{DNA}}$ as dependent variables.

\section{RESULTS}

\section{Cross-Sectional Study}

The GEM TLip content of liver biopsy samples from 33 cows obtained on d 14 p.p. was $10.0 \%$ with an interquartile range from 6.1 to $13.4 \%$ (total range, 3.6 to $24.9 \%$ ). The GEM TAG content was $4.0 \%$, with an interquartile range of 2.0 to $8.0 \%$ (total range, 0.2 to $19.9 \%$ ) and $\mathrm{W}$ content was $67.0 \pm 4.4 \%$. Mean DMI was $18.3 \pm 3.7 \mathrm{~kg} / \mathrm{d}$ and milk yield was $35.0 \pm 8.3$ $\mathrm{kg} / \mathrm{d}$. Seven biopsy samples could not be assayed for DNA content because of insufficient liver tissue. The DNA content in the remaining 26 samples was 0.94 $\pm 0.34 \mathrm{mg} / \mathrm{g}$ of wet tissue. Mean values for $\mathrm{P}, \mathrm{K}, \mathrm{Mg}$, $\mathrm{Na}$, and $\mathrm{Ca}$ in dry liver tissue $\left(\mathrm{P}_{\mathrm{DW}}, \mathrm{K}_{\mathrm{DW}}, \mathrm{Mg}_{\mathrm{DW}}\right.$, $\mathrm{Na}_{\mathrm{DW}}$, and $\mathrm{Ca}_{\mathrm{DW}}$ respectively), wet liver tissue $\left(\mathrm{P}_{\mathrm{WW}}\right.$, $\mathrm{K}_{\mathrm{Ww}}, \mathrm{Mg}_{\mathrm{Ww}}, \mathrm{Na}_{\mathrm{Ww}}$, and $\mathrm{Ca}_{\mathrm{Ww}}$ ), nonfat wet liver tissue $\left(\mathrm{P}_{\mathrm{NFWW}}, \mathrm{K}_{\mathrm{NFWW}}, \mathrm{Mg}_{\mathrm{NFWW}}, \mathrm{Na}_{\mathrm{NFWW}}, \mathrm{Ca}_{\mathrm{NFWW}}\right)$, and indexed to DNA ( $\mathrm{P}_{\mathrm{DNA}}, \mathrm{K}_{\mathrm{DNA}}, \mathrm{Mg}_{\mathrm{DNA}}, \mathrm{Na}_{\mathrm{DNA}}, \mathrm{Ca}_{\mathrm{DNA}}$ ) are presented in Table 1. Serum biochemical values for the 33 cows on d 14 p.p. are in Table 2.

Pearson correlation analyses revealed a strong linear association between $\mathrm{P}_{\mathrm{DW}}$ and other predominantly intracellular electrolytes such as $\mathrm{K}_{\mathrm{DW}}(\mathrm{r}=0.92, P<$ $0.0001)$ and $\mathrm{Mg}_{\mathrm{DW}}(\mathrm{r}=0.98, P<0.0001)$ but weaker linear associations with predominantly extracellular cations such as $\mathrm{Na}_{\mathrm{DW}}(\mathrm{r}=0.48, P=0.0047)$ and $\mathrm{Ca}_{\mathrm{DW}}$ $(\mathrm{r}=0.45, P=0.0088)$. Liver $\mathrm{P}_{\mathrm{DW}}$ was also strongly correlated with the amount of $\mathrm{W}(\mathrm{r}=0.87, P<0.0001)$, TLip ( $\mathrm{r}=-0.86, P<0.0001)$, and the $\log$ to the base 10 of TAG (LTAG, $\mathrm{r}=-0.79, P<0.0001$, Figure 1). Strong negative correlations were found for $\mathrm{W}$ with TAG $(\mathrm{r}=-0.82, P<0.0001)$ and with TLip $(\mathrm{r}=$ $-0.78, P<0.0001)$.

Liver $\mathrm{P}_{\mathrm{Ww}}$ was correlated with $\mathrm{Mg}_{\mathrm{ww}}(\mathrm{r}=0.93, P<$ $0.0001), \mathrm{K}_{\mathrm{WW}}(\mathrm{r}=0.79, P<0.0001)$, TLip $(\mathrm{r}=-0.64$, $P<0.0001)$, and LTAG $(\mathrm{r}=-0.49, P=0.004)$. Liver $\mathrm{P}_{\text {NFWW }}$ was correlated with $\mathrm{Mg}_{\text {NFWW }}(\mathrm{r}=0.87, P<$ $0.0001), \mathrm{K}_{\mathrm{NFWW}}(\mathrm{r}=0.71, P<0.0001)$, and with the $\log$ to the base 10 of [NEFA] $(\mathrm{r}=0.45, P=0.027)$. Liver $\mathrm{P}_{\mathrm{DNA}}$ was correlated with $\mathrm{Mg}_{\mathrm{DNA}}(\mathrm{r}=0.99, P<$ $0.0001), \mathrm{K}_{\mathrm{DNA}}(\mathrm{r}=0.98, P<0.0001)$, and $\mathrm{Ca}_{\mathrm{DNA}}(\mathrm{r}=$ $0.81, P<0.0001)$.

The liver DNA content was found to be correlated with BHBA $(\mathrm{r}=-0.64, P=0.0043),[\mathrm{CHOL}](\mathrm{r}=$

Table 2. Serum biochemical values for 33 lactating Holstein-Friesian cows on d 14 after calving ${ }^{1}$

\begin{tabular}{lc}
\hline Parameter & $\begin{array}{c}\text { Mean } \pm \text { SD or GEM and } \\
\text { [interquartile range] }\end{array}$ \\
\hline Urea $(\mathrm{mg} / \mathrm{dL})$ & $13.8 \pm 2.7$ \\
Total protein $(\mathrm{g} / \mathrm{dL})$ & $7.3 \pm 0.6$ \\
Albumin $(\mathrm{g} / \mathrm{dL})$ & $3.0 \pm 0.4$ \\
Glucose $(\mathrm{mg} / \mathrm{dL})$ & $55[49$ to 58$]$ \\
Insulin $(\mu \mathrm{U} / \mathrm{mL})$ & $1.2[0.6$ to 3.1$]$ \\
BHBA $(\mathrm{mg} / \mathrm{dL})$ & $5.6 \pm 1.6$ \\
NEFA $(\mu \mathrm{Eq} / \mathrm{L})$ & $354[327$ to 457$]$ \\
Cholesterol $(\mathrm{mg} / \mathrm{dL})$ & $87 \pm 20$ \\
Sorbitol dehydrogenase $(\mathrm{U} / \mathrm{L})$ & $5.9[3.8$ to 8.8$]$ \\
Aspartate aminotransferase $(\mathrm{U} / \mathrm{L})$ & $80[68$ to 92$]$ \\
Alkaline phosphatase $(\mathrm{U} / \mathrm{L})$ & $27 \pm 8$ \\
$\gamma$ Glutamyl transferase $(\mathrm{U} / \mathrm{L})$ & $23 \pm 7$ \\
Total bilirubin $(\mathrm{mg} / \mathrm{dL})$ & $0.3 \pm 0.1$ \\
Na $(\mathrm{mmol} / \mathrm{L})$ & $136 \pm 0.5$ \\
$\mathrm{~K}(\mathrm{mmol} / \mathrm{L})$ & $4.4 \pm 0.5$ \\
Mg $(\mathrm{mmol} / \mathrm{L})$ & $2.0 \pm 0.5$ \\
$\mathrm{P}(\mathrm{mg} / \mathrm{dL})$ & $5.2 \pm 1.0$ \\
Ca $(\mathrm{mg} / \mathrm{dL})$ & $8.9 \pm 1.6$ \\
\hline
\end{tabular}

${ }^{1}$ Values are expressed as mean \pm standard deviation concentrations or activities or geometric mean (GEM) and interquartile range. 


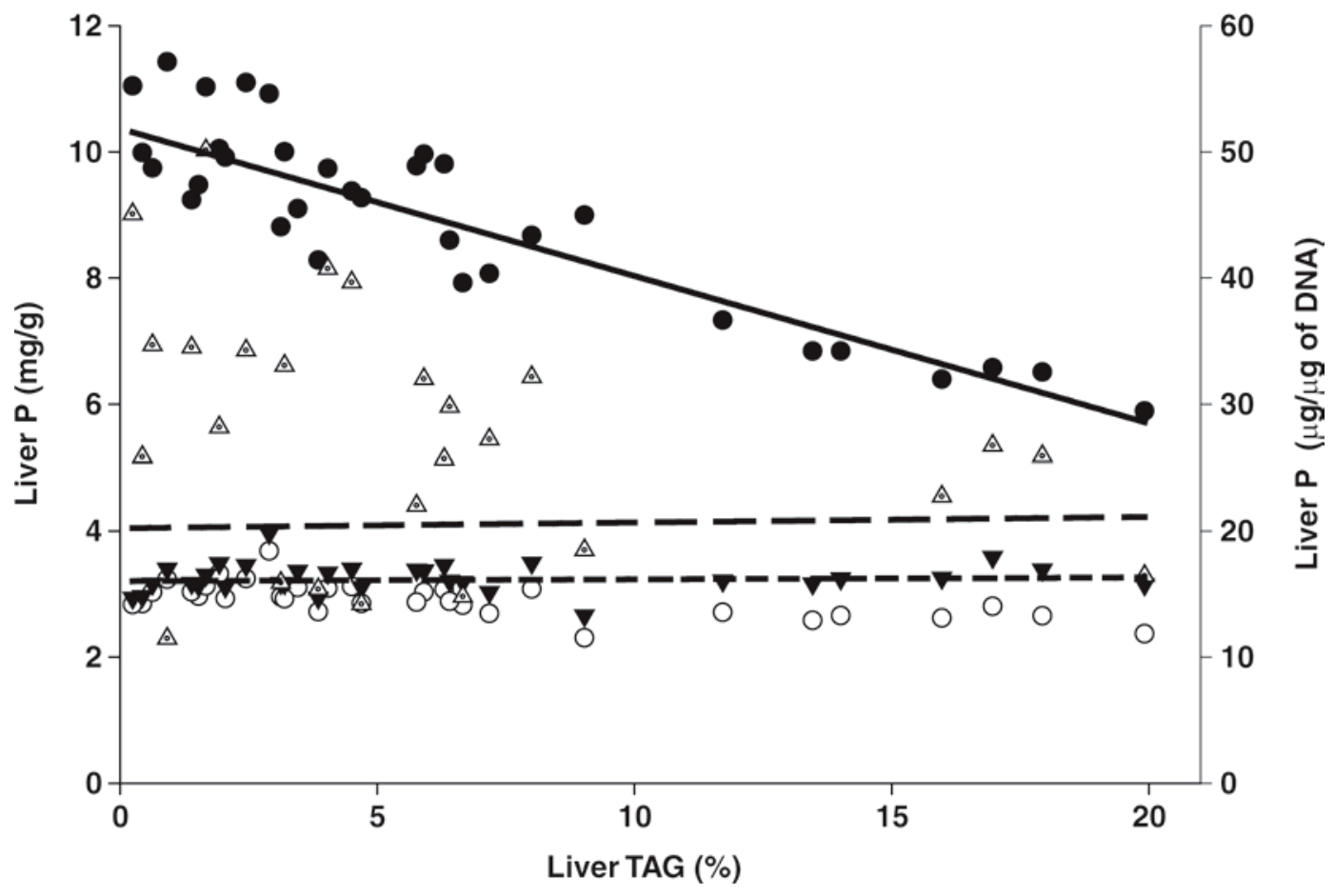

Figure 1. Associations of liver triacylglycerol (TAG) content with amount of $\mathrm{P}$ in dry liver tissue (closed circles, solid regression line), wet liver tissue (open circles, dotted regression line), and nonfat wet liver tissue (solid triangles, short dashed regression line) and P indexed to liver DNA (open triangles, long dashed regression line, $\mathrm{n}=26$ ) in 33 lactating Holstein-Friesian cows biopsied on d 14 after calving.

$-0.64, P=0.0033), \mathrm{W}(\mathrm{r}=0.41, P=0.0292), \mathrm{DMI}(\mathrm{r}$ $=-0.51, P=0.0269)$, and milk yield $(\mathrm{r}=-0.45, P=$ 0.0211). Accordingly, negative correlations were found between $\mathrm{P}_{\mathrm{DNA}}$ and BHBA $(\mathrm{r}=-0.63, P=0.0051)$, [CHOL] $(\mathrm{r}=-0.60, P=0.0069), \mathrm{DMI}(\mathrm{r}=-0.57, P=$ $0.012)$, and milk yield $(\mathrm{r}=-0.50, P=0.0088)$.

Forward and backward multiple stepwise regression analyses revealed the strongest associations of liver $\mathrm{P}_{\mathrm{DW}}$ with $\mathrm{W}$ (partial $\mathrm{R}^{2}=0.74, P<0.0001$ ) and LTAG (partial $\mathrm{R}^{2}=0.05, P=0.03$ ), whereas no significant associations were found between $\mathrm{P}_{\mathrm{NFWW}}$ and measured parameters. Liver $\mathrm{P}_{\mathrm{ww}}$ only showed an association with LTAG (partial $\mathrm{R}^{2}=0.30, P=0.004$ ) and liver $\mathrm{P}_{\mathrm{DNA}}$ was most strongly associated with $[\mathrm{BHBA}]$ (partial $\mathrm{R}^{2}$ $=0.40, P=0.005)$ and $\log$ to the base 10 of AST (partial $\mathrm{R}^{2}=0.18, P=0.02$ ).

A moderate negative correlation was identified between LTAG and $\mathrm{W}(\mathrm{r}=-0.73, P<0.0001)$ and a weaker positive correlation between LTAG and $\mathrm{W}+$ TLip ( $\mathrm{r}=0.53, P=0.0015$, Figure 2). No significant correlations were detected between any of the liver $\mathrm{P}$ parameters and serum $\mathrm{P}$ concentration on d 14 p.p.

An analysis of covariance with DNA as a covariate revealed similar results for the associations of $\mathrm{P}_{\mathrm{DW}}$ with $\mathrm{W}$ and LTAG as well as of $\mathrm{P}_{\mathrm{ww}}$ with LTAG. The model with $\mathrm{P}_{\mathrm{NFWw}}$ as dependent and TLip or TAG as independent and the amount of DNA in liver tissue as covariate was not significant, supporting the earlier finding that $\mathrm{P}_{\mathrm{NFWw}}$ was not affected by the degree of lipid accumulation in the liver.

The ANOVA detected no differences in $\mathrm{P}_{\mathrm{WW}}, \mathrm{P}_{\mathrm{NFWW}}$, or $\mathrm{P}_{\mathrm{DNA}}$ among cows on different dietary treatments during the dry period. Biopsy samples from cows in the group with the highest TAG (7 samples) had significantly lower $\mathrm{P}_{\mathrm{DW}}$ than samples from all other groups $(P<0.034)$.

\section{Longitudinal Study}

For the 6 cows that were studied from -65 to +49 d relative to calving, liver TAG increased from $0.46 \%$ (0.21 to $1.08 \%$ GEM, interquartile range) on $\mathrm{d}-14$ to $2.43 \%$ (1.65 to $3.37 \%$ ) on $\mathrm{d}+1$ and $5.37 \%$ (2.40 to $13.03 \%)$ on d 14. By 28 d p.p., mean liver TAG had declined to $1.9 \%$ (0.56 to $7.25 \%$ ) and TAG approached values measured $14 \mathrm{~d}$ before calving by $49 \mathrm{~d}$ p.p. $(0.59 \%$, 0.31 to $1.45 \%$ ). Liver TAG values measured $14 \mathrm{~d}$ p.p. were significantly higher than values on $\mathrm{d}-65,-3$, -14 , and +49 relative to calving.

The DNA content in wet liver tissue ranged around $1 \mathrm{mg} / \mathrm{g}$ from 65 to $14 \mathrm{~d}$ before calving and again at 28 and $49 \mathrm{~d}$ p.p. Between $\mathrm{d}-14$ and $\mathrm{d}+1$, the liver DNA content in liver wet weight declined from $1.14 \pm 0.45$ to $0.71 \pm 0.46 \mathrm{mg} / \mathrm{g}(P=0.034)$, which was followed by a return to values around $1 \mathrm{mg} / \mathrm{g}(1.17 \pm 0.29 \mathrm{mg} / \mathrm{g}$, $P=0.025)$ at $28 \mathrm{~d}$ p.p. Changes over time in $\mathrm{P}_{\mathrm{DW}}$, 


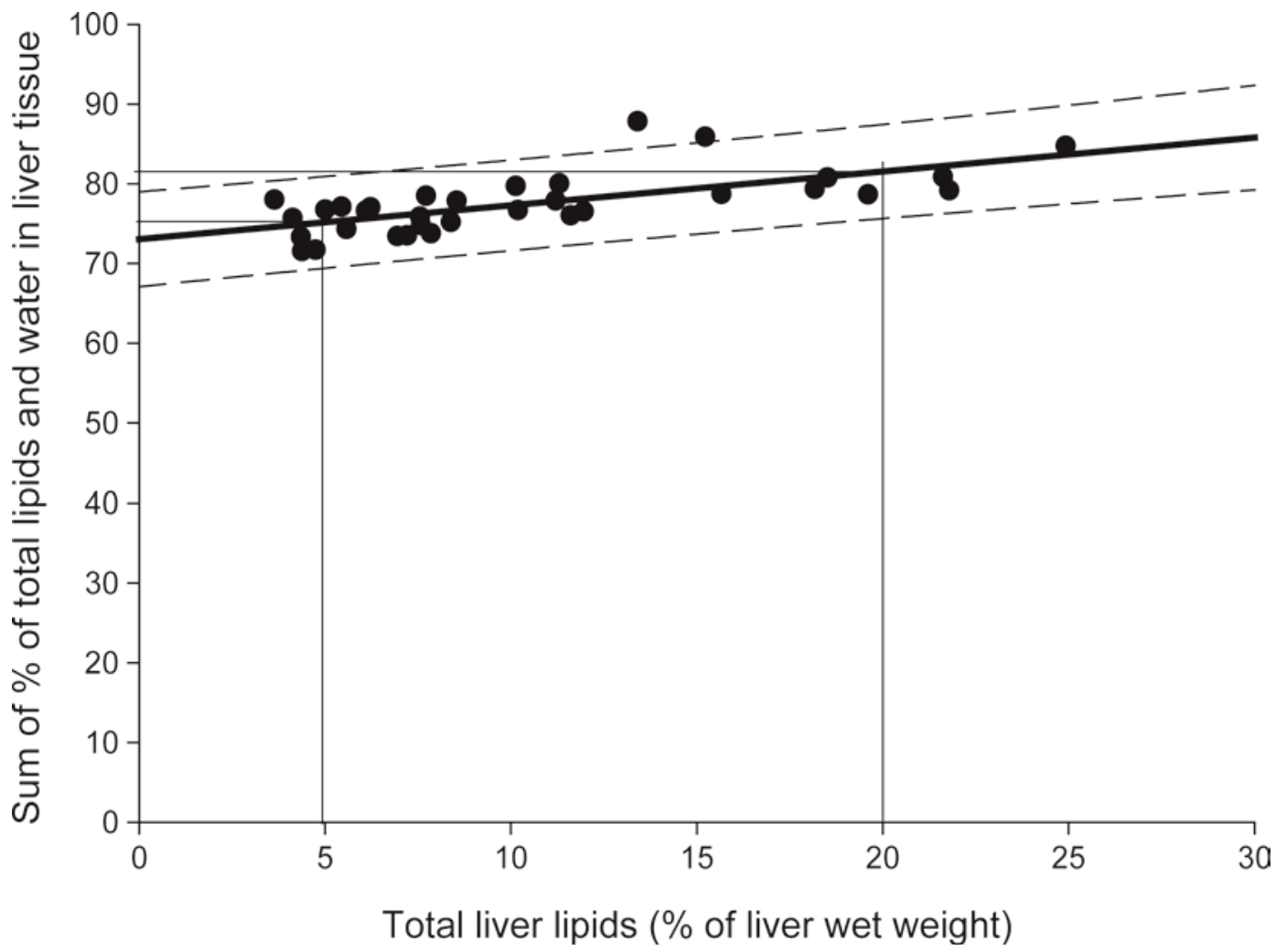

Figure 2. Association between total liver lipid content (TLip) and the sum of TLip and liver water content, which was used as a proxy for hepatocellular volume, in 33 lactating Holstein-Friesian cows biopsied $14 \mathrm{~d}$ after calving. An increase in TLip from 5 to $20 \%$ (vertical solid lines) is equivalent to an increase in cell volume of approximately $6 \%$ (solid horizontal lines). The thick solid line represents the regression line (y $=$ $\left.73.0+0.43 \mathrm{x}, \mathrm{R}^{2}=0.45, P<0.0001\right)$; the dashed line represents the $95 \%$ confidence interval.

$\mathrm{P}_{\mathrm{WW}}, \mathrm{P}_{\mathrm{NFWW}}$, and $\mathrm{P}_{\mathrm{DNA}}$ are summarized in Table 3. The $\mathrm{P}_{\mathrm{DW}}, \mathrm{P}_{\mathrm{WW}}$, and $\mathrm{P}_{\mathrm{NFWW}}$ decreased by 30,25 , and $20 \%$, respectively, between $\mathrm{d} 1$ and 14 p.p. Contents of $\mathrm{Mg}$, $\mathrm{K}, \mathrm{Na}$, and $\mathrm{Ca}$ showed similar but nonsignificant trends over time when expressed on a dry weight basis or when indexed to DNA, whereas a significant decline in nonfat wet liver tissue after calving was only detected with $\mathrm{P}$ (Figure 3).

Serum [Pi] did not change significantly throughout the period studied, but values varied considerably at all time points. Serum [Pi] increased numerically from the day of parturition to the end of the study period (Figure 4). Regression analyses with liver P parameters as dependent variables and serum $[\mathrm{Pi}]$ as independent variable revealed only weak positive associations at 28 $\mathrm{d}$ p.p. At this time point, $\mathrm{P}_{\mathrm{DW}}$ was associated with serum $[\mathrm{Pi}]\left(\mathrm{R}^{2}=0.67, P=0.046\right)$ and $\mathrm{P}_{\mathrm{Ww}}$ with serum $[\mathrm{Pi}]\left(\mathrm{R}^{2}=0.70, P=0.038\right)$.

\section{DISCUSSION}

The major focus of the study presented here was to identify potential mechanisms affecting the liver $\mathrm{P}$ con- tent in dairy cows during the transition period and to determine which of the 4 different ways of expressing the $\mathrm{P}$ content in liver tissue (i.e., $\mathrm{P}_{\mathrm{DW}}, \mathrm{P}_{\mathrm{WW}}, \mathrm{P}_{\mathrm{NFWW}}$, $\left.\mathrm{P}_{\mathrm{DNA}}\right)$ was best suited to characterize changes in intracellular electrolyte homeostasis in bovine hepatocytes.

The results from the cross-sectional study revealed a considerable decrease of the content of all measured electrolytes in liver dry weight with increasing liver lipid content. The strong association between predominantly intracellular electrolytes such as $\mathrm{P}, \mathrm{K}$, and $\mathrm{Mg}$ indicated that the changes affected predominantly intracellular electrolytes to a similar extent and were therefore not specific to $\mathrm{P}$. The weaker associations identified between the $\mathrm{P}$ content in liver dry weight and the amount of predominantly extracellular minerals in liver dry weight, such as $\mathrm{Na}$ or $\mathrm{Ca}$, support the hypothesis that the observed changes reflect changes in the intracellular compartment. The correlation and multiple stepwise regression analyses showed strong associations of the $\mathrm{P}, \mathrm{K}$, and $\mathrm{Mg}$ content in liver dry weight with the amount of $\mathrm{W}$ and, to a lesser extent, with the liver lipid content. We therefore conclude that changes in the electrolyte content in liver dry weight 
Table 3. Electrolyte content (mean $\pm \mathrm{SD}$ ) in liver tissue of 6 Holstein-Friesian cows expressed on a dry weight, wet weight, or nonfat wet weight basis or indexed to liver DNA at various sampling times relative to calving

\begin{tabular}{|c|c|c|c|c|c|}
\hline Item & $\begin{array}{l}\text { Day relative } \\
\text { to calving }\end{array}$ & Dry weight & Wet weight & Nonfat wet weight & $\begin{array}{l}\text { Indexed to DNA } \\
(\mu \mathrm{g} / \mu \mathrm{g} \text { of DNA })\end{array}$ \\
\hline \multirow[t]{7}{*}{$\mathrm{P}(\mathrm{mg} / \mathrm{g})$} & -65 & $11.87 \pm 1.33^{\mathrm{a}}$ & $3.84 \pm 0.16^{\mathrm{a}}$ & $4.03 \pm 0.17^{\mathrm{a}}$ & $3.74 \pm 1.41^{\mathrm{a}}$ \\
\hline & -30 & $11.48 \pm 1.24^{\mathrm{ab}}$ & $3.58 \pm 0.28^{\mathrm{a}}$ & $3.73 \pm 0.29^{\mathrm{ab}}$ & $3.37 \pm 0.74^{\mathrm{a}}$ \\
\hline & -14 & $12.45 \pm 1.07^{\mathrm{a}}$ & $3.74 \pm 0.30^{\mathrm{a}}$ & $3.93 \pm 0.33^{\mathrm{a}}$ & $4.23 \pm 1.65^{\mathrm{a}}$ \\
\hline & 1 & $12.00 \pm 1.61^{\mathrm{a}}$ & $3.80 \pm 0.06^{\mathrm{a}}$ & $4.10 \pm 0.05^{\mathrm{a}}$ & $2.71 \pm 1.81^{\mathrm{a}}$ \\
\hline & 14 & $8.25 \pm 1.40^{\mathrm{b}}$ & $2.91 \pm 0.46^{\mathrm{b}}$ & $3.26 \pm 0.41^{\mathrm{b}}$ & $2.42 \pm 0.77^{\mathrm{a}}$ \\
\hline & 28 & $10.16 \pm 2.08^{\mathrm{ab}}$ & $3.51 \pm 0.26^{\mathrm{a}}$ & $3.80 \pm 0.21^{\mathrm{a}}$ & $4.12 \pm 1.18^{\mathrm{a}}$ \\
\hline & 49 & $11.68 \pm 1.53^{\mathrm{a}}$ & $3.75 \pm 0.22^{\mathrm{a}}$ & $3.95 \pm 0.20^{\mathrm{a}}$ & $3.49 \pm 1.27^{\mathrm{a}}$ \\
\hline \multirow[t]{7}{*}{$\mathrm{Mg}(\mu \mathrm{g} / \mathrm{g})$} & -65 & $488.3 \pm 51.6^{\mathrm{a}}$ & $158.0 \pm 7.33^{\mathrm{a}}$ & $165.6 \pm 6.6^{\mathrm{a}}$ & $0.15 \pm 0.06^{\mathrm{a}}$ \\
\hline & -30 & $485.8 \pm 52.4^{\mathrm{a}}$ & $151.6 \pm 13.4^{\mathrm{a}}$ & $158.1 \pm 13.9^{\mathrm{a}}$ & $0.14 \pm 0.03^{\mathrm{a}}$ \\
\hline & -14 & $530.5 \pm 65.5^{\mathrm{a}}$ & $159.0 \pm 11.1^{\mathrm{a}}$ & $166.7 \pm 12.6^{\mathrm{a}}$ & $0.18 \pm 0.06^{\mathrm{a}}$ \\
\hline & 1 & $521.6 \pm 73.8^{\mathrm{a}}$ & $165.3 \pm 9.7^{\mathrm{a}}$ & $178.5 \pm 10.0^{\mathrm{a}}$ & $0.12 \pm 0.09^{\mathrm{a}}$ \\
\hline & 14 & $426.9 \pm 69.8^{\mathrm{a}}$ & $148.9 \pm 22.5^{\mathrm{a}}$ & $168.9 \pm 19.9^{\mathrm{a}}$ & $0.13 \pm 0.04^{\mathrm{a}}$ \\
\hline & 28 & $444.4 \pm 84.7^{\mathrm{a}}$ & $153.5 \pm 6.6^{\mathrm{a}}$ & $166.3 \pm 5.0^{\mathrm{a}}$ & $0.18 \pm 0.05^{\mathrm{a}}$ \\
\hline & 49 & $486.5 \pm 54.7^{\mathrm{a}}$ & $156.5 \pm 7.4^{\mathrm{a}}$ & $164.6 \pm 6.5^{\mathrm{a}}$ & $0.14 \pm 0.05^{\mathrm{a}}$ \\
\hline \multirow[t]{7}{*}{$\mathrm{K}(\mathrm{mg} / \mathrm{g})$} & -65 & $8.28 \pm 1.13^{\mathrm{a}}$ & $2.68 \pm 0.27^{\mathrm{a}}$ & $2.81 \pm 0.27^{\mathrm{a}}$ & $2.65 \pm 1.10^{\mathrm{a}}$ \\
\hline & -30 & $7.84 \pm 1.17^{\mathrm{a}}$ & $2.45 \pm 0.32^{\mathrm{a}}$ & $2.55 \pm 0.33^{\mathrm{a}}$ & $2.31 \pm 0.59^{\mathrm{a}}$ \\
\hline & -14 & $9.27 \pm 1.13^{\mathrm{a}}$ & $2.77 \pm 0.21^{\mathrm{a}}$ & $2.91 \pm 0.25^{\mathrm{a}}$ & $3.10 \pm 1.13^{\mathrm{a}}$ \\
\hline & 1 & $8.76 \pm 1.25^{\mathrm{a}}$ & $2.78 \pm 0.27^{\mathrm{a}}$ & $3.01 \pm 0.28^{\mathrm{a}}$ & $2.03 \pm 1.52^{\mathrm{a}}$ \\
\hline & 14 & $7.47 \pm 1.15^{\mathrm{a}}$ & $2.60 \pm 0.33^{\mathrm{a}}$ & $2.95 \pm 0.28^{\mathrm{a}}$ & $2.18 \pm 0.60^{\mathrm{a}}$ \\
\hline & 28 & $7.48 \pm 1.25^{\mathrm{a}}$ & $2.59 \pm 0.08^{\mathrm{a}}$ & $2.81 \pm 0.17^{\mathrm{a}}$ & $3.03 \pm 0.77^{\mathrm{a}}$ \\
\hline & 49 & $8.18 \pm 0.86^{\mathrm{a}}$ & $2.63 \pm 0.12^{\mathrm{a}}$ & $2.77 \pm 0.10^{\mathrm{a}}$ & $2.44 \pm 0.82^{\mathrm{a}}$ \\
\hline \multirow{7}{*}{$\mathrm{Na}(\mathrm{mg} / \mathrm{g})$} & -65 & $4.75 \pm 3.88^{\mathrm{a}}$ & $1.57 \pm 1.35^{\mathrm{a}}$ & $1.65 \pm 1.42^{\mathrm{a}}$ & $1.51 \pm 1.44^{\mathrm{a}}$ \\
\hline & -30 & $3.69 \pm 0.75^{\mathrm{a}}$ & $1.15 \pm 0.23^{\mathrm{a}}$ & $1.20 \pm 0.23^{\mathrm{a}}$ & $1.08 \pm 0.30^{\mathrm{a}}$ \\
\hline & -14 & $3.43 \pm 0.53^{\mathrm{a}}$ & $1.02 \pm 0.10^{\mathrm{a}}$ & $1.07 \pm 0.09^{\mathrm{a}}$ & $1.20 \pm 0.53^{\mathrm{a}}$ \\
\hline & 1 & $3.21 \pm 0.56^{\mathrm{a}}$ & $1.01 \pm 0.09^{\mathrm{a}}$ & $1.10 \pm 0.10^{\mathrm{a}}$ & $0.70 \pm 0.39^{\mathrm{a}}$ \\
\hline & 14 & $3.04 \pm 0.83^{\mathrm{a}}$ & $1.07 \pm 0.36^{\mathrm{a}}$ & $1.22 \pm 0.38^{\mathrm{a}}$ & $0.91 \pm 0.43^{\mathrm{a}}$ \\
\hline & 28 & $3.08 \pm 0.78^{\mathrm{a}}$ & $1.06 \pm 0.13^{\mathrm{a}}$ & $1.14 \pm 0.10^{\mathrm{a}}$ & $1.23 \pm 0.31^{\mathrm{a}}$ \\
\hline & 49 & $3.02 \pm 0.29^{\mathrm{a}}$ & $0.97 \pm 0.84^{\mathrm{a}}$ & $1.02 \pm 0.09^{\mathrm{a}}$ & $0.90 \pm 0.31^{\mathrm{a}}$ \\
\hline \multirow[t]{7}{*}{$\mathrm{Ca}(\mu \mathrm{g} / \mathrm{g})$} & -65 & $153.7 \pm 18.5^{\mathrm{a}}$ & $49.9 \pm 6.0^{\mathrm{a}}$ & $52.3 \pm 6.6^{\mathrm{a}}$ & $0.05 \pm 0.01^{\mathrm{a}}$ \\
\hline & -30 & $179.7 \pm 43.3^{\mathrm{a}}$ & $56.0 \pm 12.2^{\mathrm{a}}$ & $58.3 \pm 12.7^{\mathrm{a}}$ & $0.05 \pm 0.02^{\mathrm{a}}$ \\
\hline & -14 & $177.4 \pm 26.8^{\mathrm{a}}$ & $53.0 \pm 3.6^{\mathrm{a}}$ & $55.6 \pm 3.8^{\mathrm{a}}$ & $0.06 \pm 0.03^{\mathrm{a}}$ \\
\hline & 1 & $153.2 \pm 23.6^{\mathrm{a}}$ & $48.5 \pm 2.4^{\mathrm{a}}$ & $52.3 \pm 2.6^{\mathrm{a}}$ & $0.03 \pm 0.02^{\mathrm{a}}$ \\
\hline & 14 & $136.5 \pm 29.8^{\mathrm{a}}$ & $48.1 \pm 12.8^{\mathrm{a}}$ & $54.6 \pm 13.2^{\mathrm{a}}$ & $0.04 \pm 0.02^{\mathrm{a}}$ \\
\hline & 28 & $143.7 \pm 28.7^{\mathrm{a}}$ & $49.7 \pm 4.7^{\mathrm{a}}$ & $53.8 \pm 5.0^{\mathrm{a}}$ & $0.06 \pm 0.02^{\mathrm{a}}$ \\
\hline & 49 & $144.0 \pm 15.2^{\mathrm{a}}$ & $46.5 \pm 3.9^{\mathrm{a}}$ & $48.9 \pm 4.3^{\mathrm{a}}$ & $0.04 \pm 0.02^{\mathrm{a}}$ \\
\hline
\end{tabular}

${ }^{\mathrm{a}, \mathrm{b}}$ Values with different superscript letters within a column and item differ significantly $(P<0.05)$.

are driven by changes in $\mathrm{W}$ volume, thereby directly affecting the distribution volume of unbound, ionized electrolytes.

We used changes in $\mathrm{W}$ volume as a proxy for intracellular volume changes. We chose this simple approach to crudely estimate intracellular volume changes because swelling of rat liver tissue is associated with an increase in tissue water volume that is largely due to an increase in intracellular volume, with changes in extracellular volume being of minor importance (Parsons and Rossum, 1962). A decrease in $\mathrm{W}$ volume due to a decrease in cell water volume can also explain the strong associations between intracellular electrolytes in dry liver tissue and the weaker associations determined between intracellular and extracellular electrolytes in dry liver tissue. This finding indicates that indexing the amount of an intracellular electrolyte to the wet tissue weight is more appropriate than indexing on a dry weight basis because indexing to wet tissue weight adjusts for changes in $\mathrm{W}$ volume.
We identified strong negative correlations between the $\mathrm{W}$ content and the TAG content in liver tissue of periparturient dairy cows. These findings indicate that as the liver lipid content increases, $\mathrm{W}$ content decreases concomitantly and thus it seems likely that cytosolic volume also decreases. Because in this case a decline in cell water volume is accompanied by an increase in cell lipid volume, the change in cytosol volume will neither entirely be reflected in the wet weight nor wet volume of the liver tissue. This implies that if changes in the cytosolic electrolyte concentration are to be assessed, it is imperative to subtract the fat fraction that does not contribute to the distribution volume of electrolytes from the liver mass when expressing the electrolyte content on a wet weight basis. We therefore not only calculated the electrolyte contents in liver wet weight but also in liver nonfat wet weight. The correlation and multiple stepwise regression analysis showed an association between $\mathrm{P}$ and TAG content in liver wet weight, whereas $\mathrm{P}$ expressed as amount in nonfat wet 


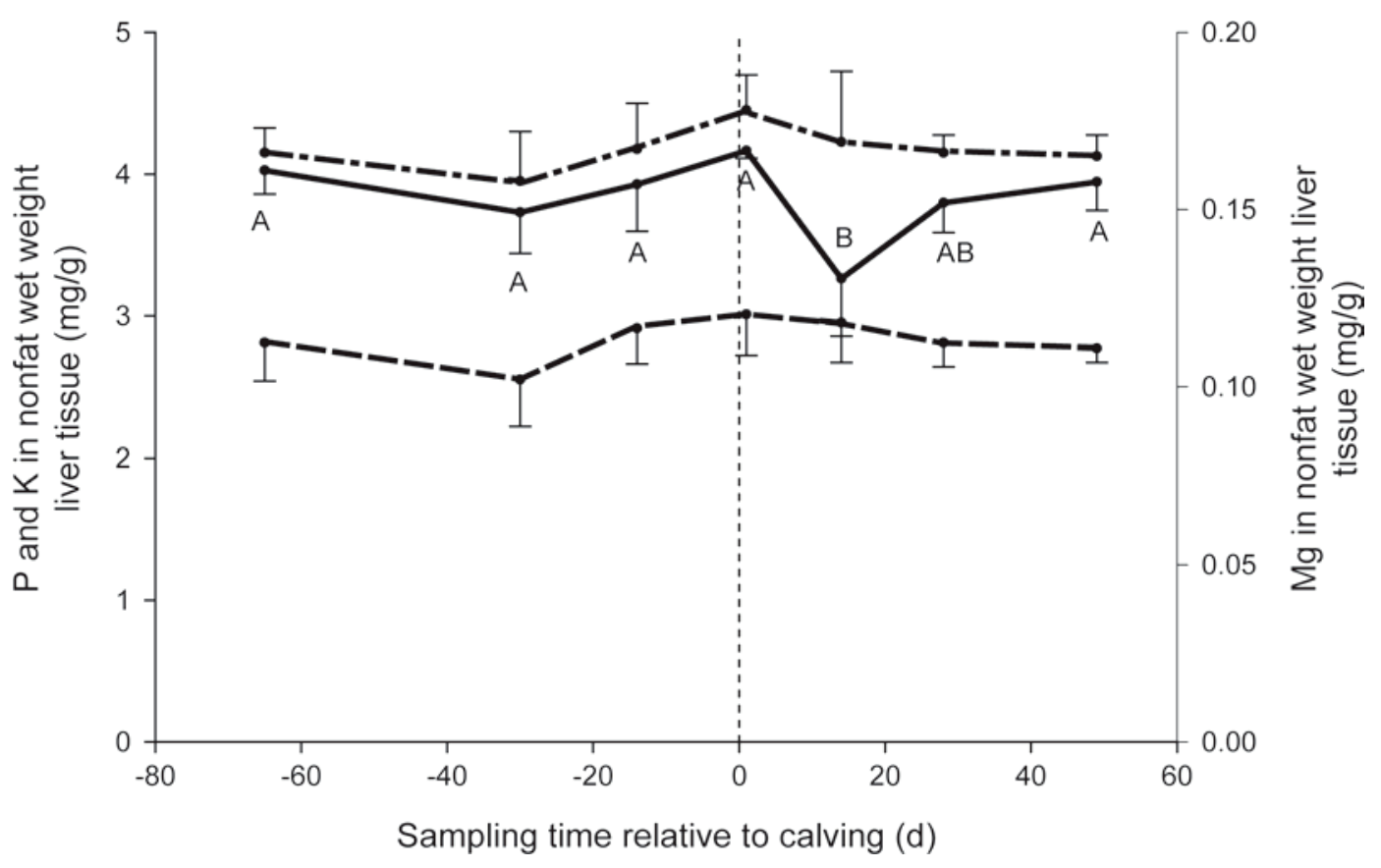

Figure 3. Amounts of $\mathrm{P}$ (solid line), $\mathrm{K}$ (dashed line), and $\mathrm{Mg}$ (dash-dotted line) in nonfat wet liver tissue from 6 Holstein-Friesian cows biopsied at various time points relative to calving. Time points with different letters are significantly different $(P<0.05$, Bonferroni-adjusted).

liver tissue was found to be independent of the liver lipid content. These findings suggest that the driving force behind the changes in the electrolyte content in liver tissue is a regulatory effort of the cell to keep the cytosolic electrolyte concentration within narrow limits as the cytosol volume changes (Figure 1). When the cell water volume decreases, concomitantly reducing the total amount of soluble electrolyte in the remaining cell water is the only way to maintain a constant cytosolic electrolyte concentration and thus a constant osmotic and electrochemical equilibrium between intracellular and extracellular space.

To better understand how the concomitant changes of cytosolic volume and TAG content affect the hepatocyte volume, we used the change in the sum of the TLip and W content (TLip $+\mathrm{W}$ ) as an approximation to determine the changes occurring in liver cell volume (Figure 2). Previous studies showed that despite considerable changes in liver mass throughout lactation and dry period, the fat-free DM content in liver tissue remains constant (Smith and Baldwin, 1974; Gibb et al., 1992). We therefore assumed that if the fraction of fat-free DM is constant, an increase in liver lipid content without an equivalent decrease in $\mathrm{W}$ content must result in a net increase in cell volume that can be estimated by the change in the sum of $\mathrm{W}$ and fat. Results of the regression analysis between TLip and the sum of TLip $+\mathrm{W}$ indicate that an increase in liver fat content results only to a minor degree in an increase in cell volume (Figure 2, Figure 5). Negative associations between $\mathrm{W}$ and liver lipid content have been reported in earlier studies (Baird et al., 1968; Carr et al., 1973; Rosendo and McDowell, 2003) and are likely the result of compensatory mechanisms regulating the liver cell volume, which is a critical determinant of liver cell and organ function (Dunkelberg et al., 2001). Swelling of hepatocytes with fat induces a regulatory cytosolic volume decrease (Häussinger and Lang, 1991; Bear, 1990) that must be accompanied by a reduction of intracellular electrolyte content if the osmotic equilibrium between intra- and extracellular environment is to be maintained. Changes in liver mass in dairy cows occurring during the transition period are considerable with increases of $11 \%$ in the first $8 \mathrm{wk}$ and of $25 \%$ in the first $12 \mathrm{wk}$ of lactation (Gibb et al., 1992; Reynolds et al., 2004). Nonetheless, these large increases in liver mass occur while the liver water content and protein content remain constant, implying that the major driving force for this increase in liver mass is an increase in the number of liver cells but not an increase of the fat or $\mathrm{W}$ fraction in the liver.

Indexing specific compounds in liver tissue to DNA has been recommended instead of indexing to liver wet or dry weight (Greenfield et al., 2000). When the content of compounds available in large amounts, such as TAG, is expressed as a fraction of the total tissue mass, changes in the content of the compound affect both the numerator and denominator of the fraction and 


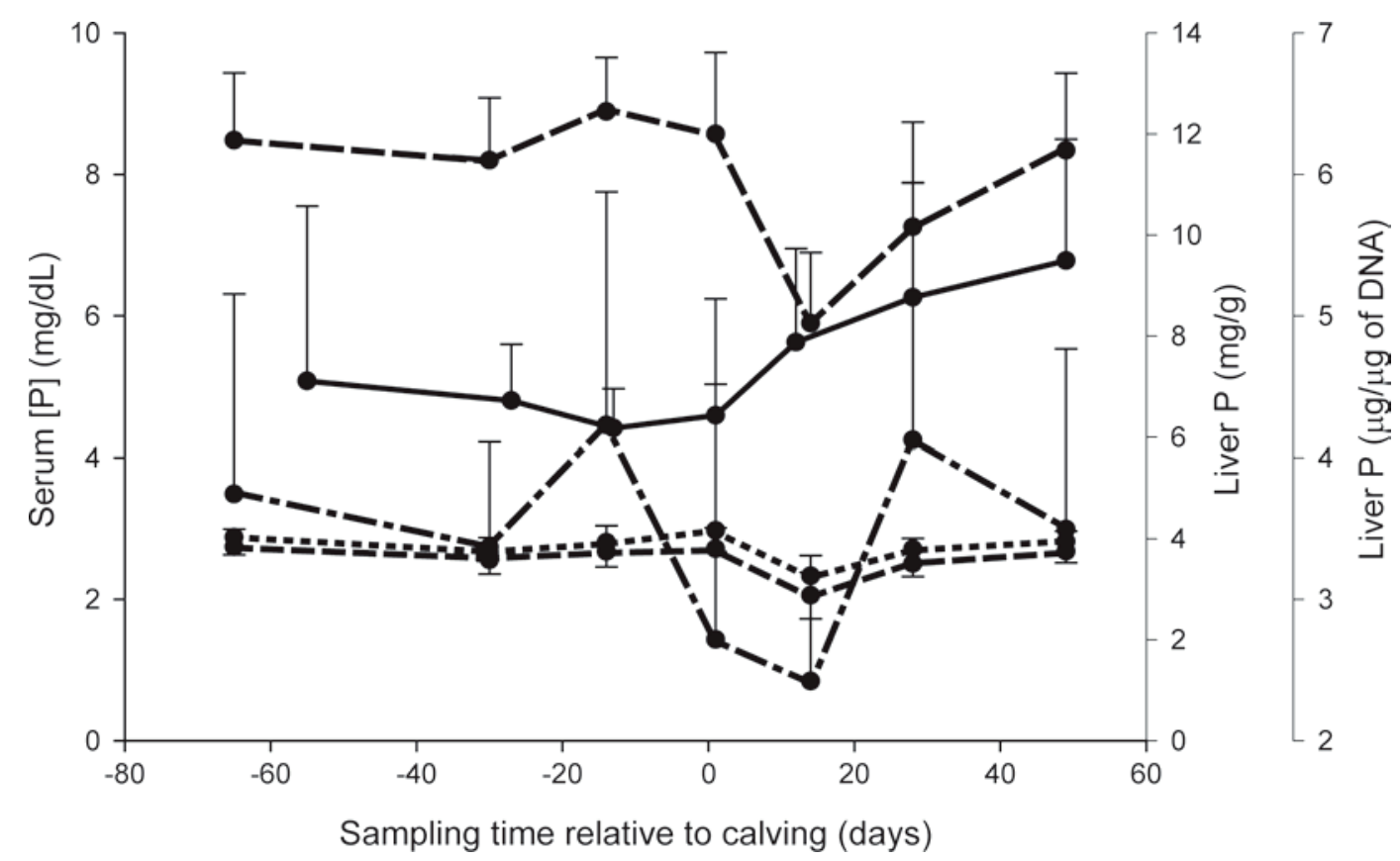

Figure 4. Serum $\mathrm{P}$ concentration (solid line) and content of $\mathrm{P}$ in dry liver tissue (long dashed line), wet liver tissue (short dashed line), nonfat wet liver tissue (dotted line), and indexed to liver DNA (dash-dotted line) for 6 Holstein-Friesian cows sampled at various time points relative to calving. Note that indexing to DNA produces much greater variability (larger value for SD) than indexing to nonfat wet weight.

can potentially result in an erroneous assessment of the change in content. For compounds contributing only $1 \%$ or less of the liver weight, as is the case for minerals, the effect of the electrolyte content on the weight of the liver tissue is negligible and indexing to DNA is unlikely to improve accuracy over that provided by liver wet or dry weight. It is commonly assumed that the DNA content per cell remains constant but in the study presented here the DNA content in liver tissue was found to be associated with the metabolic activity and varied with the stage of lactation, a finding that is in agreement with results reported in other studies (Mills et al., 1986; Greenfield et al., 2000). This implies that changes or correlations determined for the electrolyte content when indexed to DNA will be confounded by the changes or correlations associated with liver DNA rather than the mineral in question. In the study presented here, the variation of the mineral content was considerably higher when indexed to DNA than when expressed on a dry weight, wet weight, or fat-free wet weight basis, further suggesting that indexing to DNA is unsuitable to express the mineral content in liver tissue (Table 1, Figure 1). Current knowledge of cell biology and the results of the cross-sectional study suggest that the cytosolic electrolyte concentration is the critical parameter that is regulated by the liver cell; this implies that intracellular electrolytes should be expressed on a nonfat wet weight basis. The lack of correlations of electrolyte contents in nonfat wet liver tissue with the contents in dry liver tissue or indexed to DNA indicates that neither of the latter parameters sufficiently reflect changes occurring in cytosolic electrolyte concentrations.

In the longitudinal study, liver TAG and TLip increased from calving to d 14 p.p. and then decreased to the prepartum value; this finding is consistent with those reported in numerous other studies (Baird et al., 1968; Rosendo and McDowell, 2003; Bobe et al., 2004). The content of predominantly intracellular electrolytes in liver dry weight concomitantly declined and reached a nadir at $14 \mathrm{~d}$ p.p. (Table 3). During the same time, a decline of the $\mathrm{P}_{\mathrm{NFWW}}$ in liver tissue of approximately $20 \%$ was present on d 14 p.p., whereas the electrolyte content in nonfat wet liver weight of all other studied electrolytes remained unchanged over time.

We believe this is the first study to document a decrease in hepatic cytosolic $[\mathrm{P}]$ in early lactation cows. Our study design did not allow us to determine the underlying mechanisms for the decline in cytosolic [P] on d 14 p.p. We speculate that this transient decline in the amount of $\mathrm{P}$ available to liver tissue could be the result of a sudden and generalized depletion of $\mathrm{Pi}$ due to the sudden and large P losses through the mammary gland. It is also possible that insulin resistance commonly observed in dairy cows at the onset of lactation contributes to intracellular $\mathrm{P}$ depletion of 


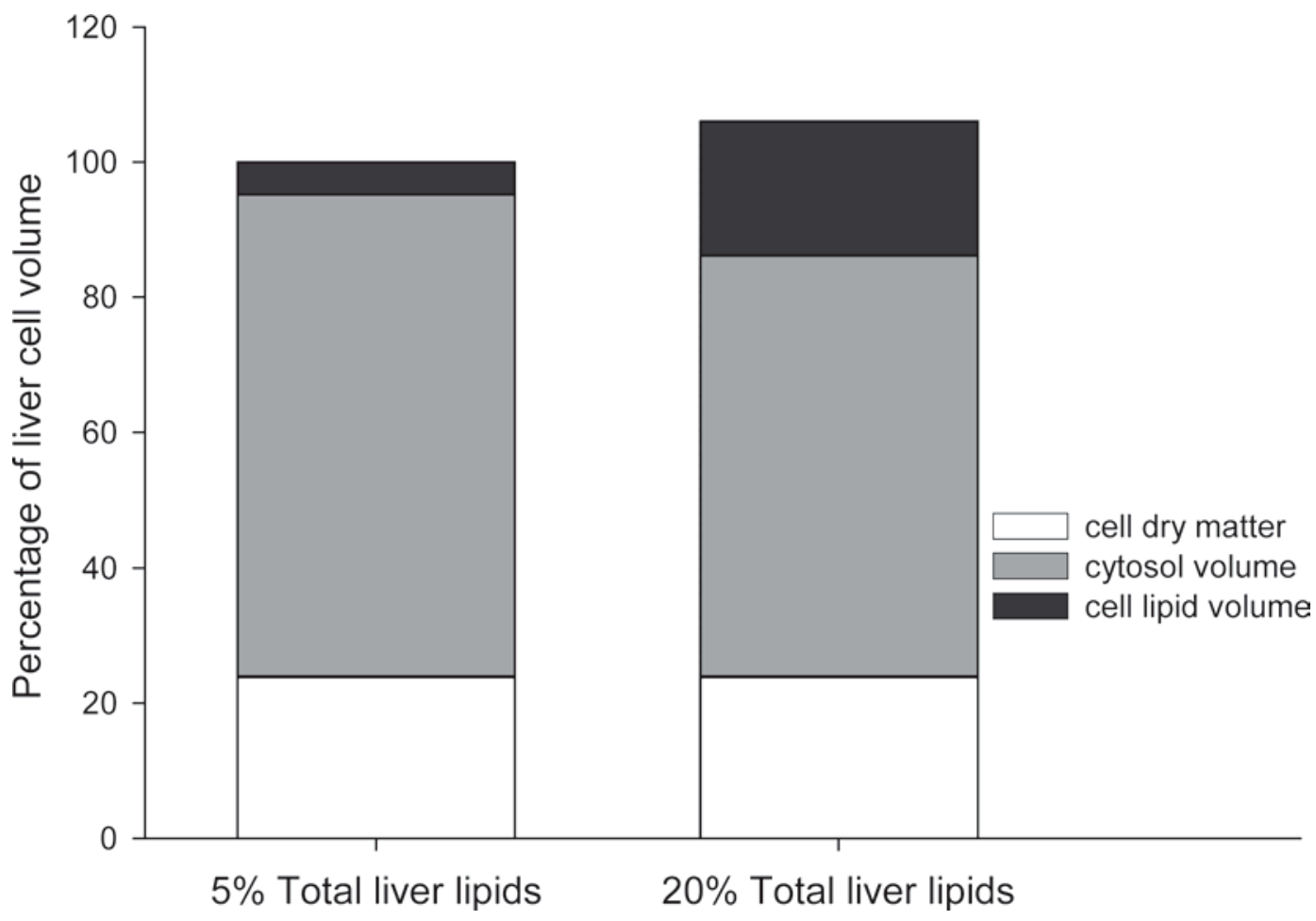

Figure 5. Schematic representation of changes affecting cytosol volume, lipid volume, and total cell volume of a hepatocyte with increasing total liver lipid content (from 5 to $20 \%$ ). The total cell volume of a liver cell with $5 \%$ total liver lipid content in this figure is considered as $100 \%$.

insulin responsive cells such as hepatocytes by reducing insulin-dependent intracellular P uptake (Grünberg et al., 2006).

We observed considerable cow-to-cow variability in serum $[\mathrm{P}]$ and the amount of $\mathrm{P}$ in liver tissue over time. This variability, along with the absence of a significant correlation between liver $\mathrm{P}$ parameters and serum $[\mathrm{P}]$, indicate that serum $[\mathrm{P}]$ should not be used to estimate liver $\mathrm{P}$ content or the changes in liver $\mathrm{P}$ content occurring over time (Figure 4).

The liver biopsies used in the study presented here were obtained during previous studies in which cows were fed different combinations of far-off and close-up rations varying in their energy but providing adequate dietary minerals (Dann et al., 2006; our unpublished data). Our statistical analysis did not reveal a carryover effect of the dietary treatments on $\mathrm{P}_{\mathrm{WW}}, \mathrm{P}_{\mathrm{NFww}}$, or $\mathrm{P}_{\mathrm{DNA}}$. We believe that the lower $\mathrm{P}_{\mathrm{DW}}$ in cows in dietary group 5 was the result of the strong correlation between LTAG and $\mathrm{P}_{\mathrm{DW}}$ rather than a direct dietary carryover effect; cows in that group had higher liver TAG than cows in all other groups.

In the present study, when the $\mathrm{P}$ content in liver tissue was expressed as $\mathrm{P}$ content in nonfat wet liver weight to estimate the cytosolic electrolyte concentration, the total amount of $\mathrm{P}$ was treated as entirely water-soluble. This approach can be criticized because
$\mathrm{P}$ also forms part of insoluble organic cell compounds such as DNA and phospholipids (Flock et al., 1936; Derr and Zieve, 1976). Liver TAG accumulation does not affect the liver phospholipid content (Collins and Reid, 1980; Bobe et al., 2004). In contrast, the DNA content has been reported to be affected by metabolic activity and stage of lactation (Greenfield et al., 2000), but in view of the small amount of DNA and the small $\mathrm{P}$ fraction in the DNA molecule, we believe the effect of changing DNA content on the liver P content to be negligible. From this we conclude that changes in the total $\mathrm{P}$ content in liver tissue are largely driven by changes in the mass of the water-soluble $\mathrm{P}$ fraction. We therefore believe that even if indexing to nonfat wet liver weight does not permit determination of the absolute amount of $\mathrm{P}$ in the cytosol of liver cells, the indexing approach does provide a reasonable approximation of the changes occurring in cytosolic $[\mathrm{P}]$.

The clinical significance of decreased cytosolic $[\mathrm{P}]$ in the hepatocytes of dairy cows in early lactation remains to be determined. Phosphorus plays an important role in hepatic carbohydrate metabolism, in which all intermediates in the gluconeogenic pathway must be phosphorylated, and the rate of gluconeogenesis as well as glycolysis is regulated by the availability of $\mathrm{Pi}$ (Berg et al., 2006). It is possible, therefore, that the $20 \%$ decrease in cytosolic $\mathrm{P}$ concentration on d 14 p.p. (Figure 
4) affected the metabolic activity of the liver. In human medicine, an association between $\mathrm{P}$ depletion of the organism and disturbed liver function is widely accepted and supplementation of $\mathrm{Pi}$ to humans with acute liver failure improves treatment outcome and reduces the complication rate (Knochel, 1977; Dawson et al., 1987; Baquerizo et al., 2003). In dairy cows, hypophosphatemia often accompanies disturbed liver function resulting from hepatic lipidosis, and hepatic lipidosis most commonly occurs in early lactation (Bobe et al., 2004). To our knowledge, a direct causative relationship between hypophosphatemia and disturbed liver function has not been proven, but associations between serum $[\mathrm{P}]$ and serum biochemical indicators of hepatic function or injury have been reported (Staufenbiel and Gelfert, 2002; Grünberg et al., 2005). Results of the study reported here do not conclusively demonstrate a direct causative relationship between serum or hepatocellular $[\mathrm{P}]$ and liver damage. Nonetheless, we believe that our results warrant further investigation of the clinical effects of $\mathrm{P}$ supplementation in dairy cows with disturbed liver function during early lactation.

\section{CONCLUSIONS}

Results of the study reported here indicate that hepatic electrolyte contents should be indexed to nonfat wet weight in lactating dairy cows with varying degrees of hepatic lipidosis. Indexing to nonfat wet weight appears to be more appropriate than indexing to dry weight, wet weight, or DNA. During the postparturient period, the liver content of most predominantly intracellular electrolytes in liver nonfat wet weight is constant; however, the $\mathrm{P}$ content in nonfat wet weight is decreased by approximately $20 \%$ on d 14 p.p. Further research is needed to determine if $\mathrm{P}$ supplementation is clinically beneficial in postparturient cows with hepatic lipidosis because such cows are likely to have an increased demand for $\mathrm{P}$ in the liver at a time of decreased liver $\mathrm{P}$ availability.

\section{ACKNOWLEDGMENTS}

We acknowledge the technical assistance of W. Hurley for laboratory analyses and Deana Rincker (both of the Department of Animal Sciences at University of Illinois) for assistance in processing samples.

\section{REFERENCES}

Baird, G. D., K. G. Hibbitt, G. D. Hunter, B. Lund, M. Stubbs, and H. A. Krebs. 1968. Biochemical aspects of bovine ketosis. Biochem. J. $107: 683-689$.

Balaban, R.S. 1984. The application of nuclear magnetic resonance to the study of cellular physiology. Am. J. Physiol. Cell Physiol. 246:C10-C19.
Baquerizo, A., D. Anselmo, C. Shackleton, T. W. Chen, C. Cao, M. Weaver, J. Gornbein, S. Geevarghese, N. Nissen, D. Farmer, A. Demetriou, and R. W. Busuttil. 2003. Phosphorus as an early predictive factor in patients with acute liver failure. Transplantation 75:2007-2014.

Bear, C. E. 1990. A nonselective cation channel in rat liver cells is activated by membrane stretch. Am. J. Physiol. 258:C421C428.

Berg, J. M., J. L. Tymoczo, and L. Stryer. 2006. Glycolysis and gluconeogenesis. Pages $433-474$ in Biochemistry. 6th ed. J. M. Berg, J. L. Tymoczo, and L. Stryer, ed. W. H. Freeman and Company, New York, NY.

Bobe, G., J. W. Young, and D. C. Beitz. 2004. Pathology, etiology, prevention, and treatment of fatty liver in dairy cows. J. Dairy Sci. 87:3105-3124.

Braselton, W. E., K. J. Stuart, T. P. Mullaney, and T. H. Herdt. 1997. Biopsy mineral analysis by inductively coupled plasma-atomic emission spectroscopy with ultrasonic nebulization. J. Vet. Diagn. Invest. 9:395-400.

Carr, T. R., D. M. Allen, and P. A. Phar. 1973. Effect of preslaughter fasting on some chemical properties of bovine muscle and liver. J. Anim. Sci. 36:923-926.

Collins, R. A., and I. M. Reid. 1980. A correlated biochemical and stereological study of periparturient fatty liver in the dairy cow. Res. Vet. Sci. 28:373-376.

Dann, H. M., N. B. Litherland, J. P. Underwood, M. Bionaz, A. D'Angelo, J. W. McFadden, and J. K. Drackley. 2006. Diets during far-off and close-up dry periods affect periparturient metabolism and lactation in multiparous cows. J. Dairy Sci. 89:3563-3577.

Dawson, D. J., C. Babbs, T. W. Warnes, and R. H. Neary. 1987. Hypophosphatemia in acute liver failure. Br. Med. J. (Clin. Res. Ed.) 295:1312-1313

Derr, R., and L. Zieve. 1976. Intracellular distribution of phosphate in the underfed rat developing weakness and coma following total parenteral nutrition. J. Nutr. 106:1398-1403.

Drackley, J. K. 1999. Biology of dairy cows during the transition period: The final frontier? J. Dairy Sci. 82:2259-2273.

Dunkelberg, J. C., A. P. Feranchak, and J. G. Fritz. 2001. Liver cell volume regulation: Size matters. Hepatology 33:1349-1352.

Fletcher, M. J. 1968. A colorimetric method for estimating serum triglycerides. Clin. Chim. Acta 22:393-397.

Flock, E., J. L. Bollman, and F. C. Mann. 1936. The effect of diet upon the phosphate compounds in the liver of the dog. J. Biol. Chem. 114:179-199.

Foster, L. B., and R. T. Dunn. 1973. Stable reagents for determination of serum triglycerides by a colorimetric Hantzsch condensation method. Clin. Chem. 19:338-340.

Gibb, M. J., W. E. Ivings, M. S. Dhanoa, and J. D. Sutton. 1992 Changes in body components of autumn-calving Holstein-Friesian cows over the first 29 weeks of lactation. Anim. Prod. 55:339360.

Greenfield, R. B., M. J. Cecava, T. R. Johnson, and S. S. Donkin. 2000. Impact of dietary protein amount and rumen undegradability on intake, peripartum liver triglyceride, plasma metabolites, and milk production in transition dairy cattle. J. Dairy Sci. 83:703-710.

Grünberg, W., P. D. Constable, U. Schröder, R. Staufenbiel, D. E. Morin, and M. Rohn. 2005. Phosphorus homeostasis in dairy cows with abomasal displacement or abomasal volvulus. J. Vet. Intern. Med. 19:894-898.

Grünberg, W., D. E. Morin, J. K. Drackley, and P. D. Constable. 2006. Effect of rapid intravenous administration of $50 \%$ dextrose solution on phosphorus homeostasis in postparturient dairy cows. J. Vet. Intern. Med. 20:1471-1478.

Hara, A., and N. S. Radin. 1978. Lipid extraction of tissue with a lowtoxicity solvent. Anal. Biochem. 90:420-426.

Häussinger, D., and F. Lang. 1991. Cell volume in the regulation of hepatic function: A mechanism for metabolic control. Biochim. Biophys. Acta 1071:331-350.

Hughes, J. P. 1962. A simplified instrument for obtaining liver biopsies in cattle. Am. J. Vet. Res. 23:1111-1112. 
Johnson, M. M., and J. P. Peters. 1993. Technical note: An improved method to quantify nonesterified fatty acids in bovine plasma. J. Anim. Sci. 71:753-756.

Kim, S. W., W. L. Hurley, I. K. Han, H. H. Stein, and R. A. Easter. 1999. Effects of nutrient intake on mammary gland growth in lactating sows. J. Anim. Sci. 77:3304-3315.

Knochel, J. P. 1977. The pathophysiology and clinical characteristics of severe hypophosphatemia. Arch. Intern. Med. 137:203-220.

Labarca, C., and K. Paigen. 1980. A simple, rapid and sensitive DNA assay procedure. Anal. Biochem. 102:344-352.

Mills, S. E., D. C. Beitz, and J. W. Young. 1986. Evidence of impaired metabolism in liver during induced lactation ketosis of dairy cows. J. Dairy Sci. 69:362-370.

NRC. 2001. Nutrient Requirements of Dairy Cattle. 7th rev. ed. Natl. Acad. Sci., Washington, DC.

Parsons, D. S., and D. V. Rossum. 1962. Observations on the size of the fluid compartments of rat liver slices in vitro. J. Physiol. 164:116-126.

Reid, I. M. 1980. Incidence and severity of fatty liver in dairy cows. Vet. Rec. 107:281-284

Reynolds, C. K., B. Durst, B. Lupoli, D. J. Humphries, and D. E. Beever. 2004. Visceral tissue mass and rumen volume in dairy cows during the transition period from late gestation to early lactation. J. Dairy Sci. 87:961-971.

Rosendo, O., and L. R. McDowell. 2003. Liver dry matter and liver lipids in periparturient dairy cows. Acta Vet. (Brno) 72:541546

Smith, N. E., and R. L. Baldwin. 1974. Effects of breed, pregnancy, and lactation on weight of organs and tissues in dairy cattle. J. Dairy Sci. 57:1055-1060.

Staufenbiel, R., and C. C. Gelfert. 2002. Clinical significance of hypophosphatemia in dairy cows. Abstract 25-818 in Proc. XXII World Buiatrics Congr.

Studer, V. A., R. R. Grummer, and S. J. Bertics. 1993. Effect of prepartum propylene glycol administration on periparturient fatty liver in dairy cows. J. Dairy Sci. 76:2931-2939.

Trenkle, A. 1972. Radioimmunoassay of plasma hormones: Review of plasma insulin in ruminants. J. Dairy Sci. 55:1200-1211.

Veenhuizen, J. J., J. K. Drackley, M. J. Richard, T. P. Sanderson, L. D. Miller, and J. W. Young. 1991. Metabolic changes in blood and liver during development and early treatment of experimental fatty liver and ketosis in cows. J. Dairy Sci. 74:4238-4252. 